\title{
BioLink
}

Jurnal Biologi Lingkungan, Industri, Kesehatan

Available online http://ojs.uma.ac.id/index.php/biolink

\section{ISOLASI DAN KARAKTERISASI BAKTERI ENDOFIT PENGHASIL ENZIM KATALASE DARI DAUN BUASBUAS (Premna pubescens Blume)}

\section{Isolation and Characterization of Endophytic Bacteria Producing Catalase Enzyme from Buasbuas (Premna pubescens Blume) Leaves}

\author{
Ahmad Shafwan Pulungan*, Diana Erawaty Tumangger \\ *Program Studi Biologi, FMIPA, Universitas Negeri Medan \\ Fakultas Biologi, Universitas Medan Area \\ *Corresponding author: E-mail: pulungan.shafwan@gmail.com
}

\begin{abstract}
Abstrak
Penelitian ini betujuan untuk mengetahui adanya bakteri endofit penghasil enzim katalase dari daun Buasbuas (Premna pubescens Blume) dan bagaimana karakteristik dari bakteri endofit penghasil enzim katalase yang terdapat daun Buasbuas (Premna pubescens Blume). Penelitian ini dilakukan dengan beberapa tahap karakterisasi yaitu karakterisasi makroskopis (morfologi), karaktersasi mikroskopis (pewarnaan gram) dan uji katalase. Teknik analisis data yang digunakan adalah teknik analisis data deskiptif. Hasil isolasi diperoleh 5 isolat bakteri endofit pada daun Buasbuas (Premna pubescens Blume) dan 3 isolat yang berpotensi menghasilkan enzim katalase.
\end{abstract}

Kata Kunci: Isolasi Bakteri, Karakterisasi Bakteri, Bakteri Endofit, Daun Buasbuas (Premna pubescens Blume), Pewarnaan Gram, Enzim Katalase

\begin{abstract}
This research aims to determine the presence of endophytic bacteria producing catalase enzyme in Buasbuas (Premna pubescens Blume) leaves and how endophytic bacteria producing catalase enzym characteristics of the Buasbuas (Premna pubescens Blume) leaves. This research was conducted with several characterization stages: macroscopic characterization (morphology), microscopic characterization (gram staining) and catalase test. Data analysis technique used is descriptive. The isolation result there are 5 isolates of endophytic bacteria and 3 isolates which have potential to produce catalase enzyme.
\end{abstract}

Keywords: Bacterial Isolation, Bacterial Characterization, Endophytic Bacteria, Leaves of Buasbuas (Premna pubescens Blume), Gram Staining, Catalase Enzyme

How to Cite: Pulungan, A.S., Tumangger, D.E. (2018), Isolasi dan Karaterisasi Bakteri Endofit Penghasil Enzim Katalase dari Daun Buasbuas (Premna pubescens Blume), BioLink. Vol.5 (1): Hal. 72-80 
Ahmad Shafwan P \& Diana E Tumangger, Isolasi dan Karaterisasi Bakteri Endofit Penghasil

PENDAHULUAN

Keanekaragaman

Indonesia merupakan kekayaan alam yang patut disyukuri. Tumbuhan merupakan salah satu sumber daya alam yang sangat penting dalam upaya pengobatan dan upaya mempertahankan kesehatan masyarakat. Hingga saat ini menurut perkiraan badan kesehatan dunia (WHO), $80 \%$ penduduk dunia masih menggantungkan dirinya pada pengobatan tradisional termasuk penggunaan obat yang berasal dari tumbuhan (Radji, 2005). Tanaman merupakan sumber kekayaan alam yang potensial di Indonesia. Banyak manfaat yang dapat diambil dari tanaman. Salah satu potensinya adalah banyak dijumpai berbagai jenis bakteri endofit yang mampu menghasilkan berbagai senyawa atau enzim yang berperan dalam kehidupan.

Bakteri endofit merupakan bakteri yang dapat hidup di dalam jaringan tanaman tanpa menimbulkan bahaya dan memiliki senyawa aktif yang sama seperti tanaman inangnya. Bakteri endofit terdapat hampir pada 300.000 jenis tumbuhan di bumi. Bakteri endofit dapat diperoleh dengan cara diisolasi dari tanaman yang permukaannya telah disterilkan ataupun dapat diekstrak untuk memperoleh bakteri yang terdapat pada jaringan tanaman (Ryan et al, 2008).
Keberadaan bakteri endofit di dalam jaringan tanaman juga diketahui dapat memicu pertumbuhan tanaman dan berperan sebagai agen pengendali hayati. Selain itu, bakteri endofit mempunyai banyak keuntungan dalam berbagai aspek kehidupan (de Sousa, 2017), senyawa yang dihasilkan bakteri endofit tertentu berpotensi dikembangkan dalam bidang medis dalam bentuk sediaan obat-obatan, pertanian dan remediasi lahan tercemar (Pulungan, ASS, 2015) dan industri. Beberapa genus dari bakteri endofit diketahui mampu menghasilkan metabolit sekunder contohnya Pseudomonas viridiflava yang mampu menghasilkan ekomisin b dan c sebagai senyawa antimikroba (Miller et al, 1998).

Salah satu bahan alami (tanaman alternatif) adalah Buasbuas (Premna pubescens Blume). Buasbuas dapat menyembuhkan berbagai penyakit diantaranya antiinflamasi, antibiotik, antimikroba, antifungi, sebagai immunostimulan, mengurangi diabetes dan sebagainya. Buasbuas (Premna pubescens Blume) memiliki berbagai macam senyawa metabolit sekunder yang menjadikannya sebagai salah satu tumbuhan yang bermanfaat sebagai obatobatan. Kandungan metabolit sekunder yang dikandung buasbuas (Premna 
pubescens Blume) adalah flavonoid (Restuati et al., 2014).

Besar kemungkinan bakteri endofit yang menetap pada daun dan batang buasbuas (Premna pubescens Blume) memiliki kemampuan mensintesis senyawa antibakteri yang sama seperti tanaman inangnya, karena pada hasil penelitian Kusumawati (2014) bahwa bakteri endofit yang diisolasi juga memiliki aktivitas antibakteri sama seperti ekstrak tanaman inangnya. Berdasarkan kemungkinan tersebut maka diperlukan pengujian dan pembuktian bahwa pada daun dan batang buasbuas (Premna pubescens Blume) terdapat bakteri endofit karena belum diketahui adanya penelitian tentang bakteri endofit yang terdapat pada daun dan batang buasbuas (Premna pubescens Blume).

Enzim katalase pada bakteri berfungsi mengurai $\mathrm{H}_{2} \mathrm{O}_{2}$ menjadi air dan oksigen. Enzim katalase adalah hemoprotein yang terdiri atas empat gugus heme. Heme inilah yang memungkinkan katalase untuk bereaksi dengan senyawa peroksida. Bakteri pada kondisi tertentu akan menghasilkan hidrogen peroksida. Hidrogen peroksida merupakan racun yang dapat merusak sistem metabolisme bakteri. Bakteri akan mengalami kematian apabila tidak dapat memecah hidrogen peroksida menjadi senyawa lain yang tidak berbahaya, pemecahan tersebut dapat dilakukan apabila terdapat enzim katalase (Cappucino dan Sherman, 2001). Senyawa peroksida yang memiliki rumus kimia $\mathrm{H}_{2} \mathrm{O}_{2}$ merupakan senyawa kimia yang memiliki sifat sebagai oksidator kuat dan sangat berbahaya bagi sel. Tumpukan peroksida dalam sel dapat menyebabkan terjadinya mutasi sel.

\section{METODE PENELITIAN}

Penelitian ini dilaksanakan di laboratorium mikrobiologi Laboratorium Biologi Universitas Negeri Medan pada bulan Maret sampai April 2018. Populasi dan sampel dalam penelitian ini adalah daun Buasbuas (Premna pubescens. Blume) yang diperoleh dari Tanjung Pura, Langkat, Sumatera Utara.

Alat yang digunakan dalam penelitian ini adalah sarung tangan, cawan petri dengan ukuran diameter $15 \mathrm{~cm}$, Laminar air-flow, mikroskop, autoklaf, inkubator, jarum ose dengan ujung bulat dan ujung runcing, bunsen, plastik wrap, pinset, botol semprot untuk alkohol, object glass, cover glass. Bahan yang digunakan dalam penelitian ini adalah daun dan batang buasbuas (Premna pubescens. Blume), alkohol 70\%, aquades, natrium hipoklorit $\mathrm{NaOCl}$ ), media Nutrient Agar (NA), bahan pewarnaan gram (safranin, 
iodine, kristal violet dan alkohol), dan bahan uji katalase

Rancangan penelitian terdiri dari pengambilan sampel daun, Sterilisasi daun, isolasi bakteri endofit, karakterisasi makroskopis, karakterisasi mikroskopis dan uji katalase.

Prosedur penelitian yang dilakukan adalah pertama mengambil sampel daun lalu dicuci dibawah air mengalir. Setelah itu dilakukan sterilisasi sampel yang terlebih dahulu dipotong dengan ukuran 2 $\mathrm{x} 2 \mathrm{~cm}$, selanjutnya disterilisasi permukaannya yaitu dengan direndam dalam alkohol $70 \%$ selama 1 menit, kemudian direndam dalam natrium hipoklorit ( $\mathrm{NaOCl}$ ) 5\% selama 5 menit dan setelah itu direndam kembali dalam alkohol 70\% selama 1 menit. Selanjutnya, dibilas sebanyak 3 kali dengan aquades steril. Kemudian Sampel yang telah disterilkan diletakkan pada media Nutrient Agar. Setelah itu, diinkubasi pada suhu ruang dalam keadaan gelap dan diamati selama 24-48 jam. Jika selama 24 jam di sekitar sampel tanaman belum menunjukkan adanya pertumbuhan mikroba, sterilisasi permukaan dikatakan berhasil. Pemurnian dilakukan dengan menginokulasikan isolat pada media NA baru dan diinkubasi selama 24 jam pada suhu $30^{\circ} \mathrm{C}$. Bakteri hasil dari isolasi dilakukan karakterisasi secara makroskopis pada media NA. Karakterisasi secara makroskopis dapat diketahui dari warna, bentuk (bulat, seperti akar, atau tidak beraturan), tepian (mulus, lobatus, bergelombang, bergerigi, dan filamentus) dan elevasi dari koloni (datar, naik, cembung, dan umbonatus). Kemudian di karakterisasi mikroskopis yang dilakukan berupa pewarnaan Gram. Pewarnaan Gram dilakukan untuk menentukan isolat bakteri endofit telah tunggal dan termasuk bakteri Gram negatif atau Gram positif lalu dilakukan uji katalase.

Teknik analisis data yang digunakan adalah teknik analisis data deskriptif. Teknik analisis data deskriptif merupakan tekhnik analisis yang dipakai untuk menganalisis data dengan mendeskripsikan atau menggambarkan data-data yang sudah dikumpulkan.

\section{HASIL DAN PEMBAHASAN}

Berdasarkan hasil isolasi dengan metode gores pada media NA di cawan petri diperoleh 5 isolat bakteri endofit dan 3 diantaranya berpotensi sebagai penghasil enzim katalase. Dari isolat yang diperoleh kemudian dilakukan karakterisasi makroskopis bakteri endofit (Tabel 1). 
Tabel 1. Karakterisasi Makroskopis Bakteri Endofit Pada Daun Buasbuas

\begin{tabular}{ccccccc}
\hline NO. SAMPEL & \multicolumn{4}{c}{ GAMBAR MORFOLOGI } & \multicolumn{2}{c}{ PERMUKAAN } \\
\cline { 3 - 6 } & & BENTUK & TEPIAN & ELEVASI & WARNA & \\
\hline 1 & D1 & Bundar & Licin & Datar & Putih & Mengkilap \\
2 & D2 & $\begin{array}{c}\text { Bundar dengan } \\
\text { tepian kerang }\end{array}$ & Berlekuk & Timbul & Putih & Mengkilap \\
3 & D3 & Bundar & Licin & Timbul & Putih & Mengkilap \\
4 & D4 & $\begin{array}{c}\text { Bundar dengan } \\
\text { tepian timbul }\end{array}$ & Berombak & Datar & Putih & Mengkilap \\
5 & D5 & Bundar & Licin & Datar & Putih & Mengkilap \\
\hline Pada & isolat & terdapat & berbagai & Menurut & Lay & (1994) bahwa
\end{tabular}

karakteristik yang berbeda dari segi berdasarkan ciri morfologi koloni bakteri bentuk koloni, tepian, elevasi, warna dan dan biakan murni maka dapat dilakukan sifat permukaan. Pada isolat D2 terdapat proses identifikasi jenis-jenis bentuk koloni bundar dengan tepian mikroorganisme, namun untuk kerang, tepian berlekuk, elevasi timbul memperoleh hasil identifikasi yang dan pada isolat D4 bundar dengan tepian sempurna maka harus dilanjutkan dengan timbul, tepian berombak, elevasi datar pewarnaan gram dan uji biokimia. Dari selebihnya berbentuk bundar, tepian licin, hasil penelitian pada uji pewarnaan gram elevasi datar dan untuk warna dan sifat ini diperoleh hasil bahwa isolat bakteri permukaan seluruh isolat memiliki warna endofit berbentuk basil dan bersifat gram putih dan permukaan mengkilap. negatif (berwarna merah).

Tabel 2. Bentuk dan Pewarnaan Gram Pada Bakteri Endofit

\begin{tabular}{ccc}
\hline SAMPEL & BENTUK & GRAM \\
\hline D1 & Basil & $(-)$ \\
D2 & Basil & $(-)$ \\
D3 & Basil & $(-)$ \\
D4 & Basil & $(-)$ \\
D5 & Basil & $(-)$ \\
\hline
\end{tabular}

Dari perwarnaan gram didapatkan negatif. Setelah dilakukan karakterisasi hasil dengan bentuk keseluruhan dari mikroskopis yaitu pewarnaan gram, masing-masing isolat yaitu berbentuk penelitian ini dilanjutkan dengan uji basil (batang) dan warna yang didapat katalase (Tabel 3).

adalah warna merah yang berarti bahwa isolat bakteri termasuk kedalam gram 
Tabel 3. Hasil Uji Katalase Pada Bakteri Endofit Daun Buasbuas

\begin{tabular}{cc}
\hline Isolat & Katalase \\
\hline D1 & $(-)$ \\
D2 & $(+)$ \\
D3 & $(+)$ \\
D4 & $(+)$ \\
D5 & $(-)$
\end{tabular}

Pada uji katalase dapat dinyatakan isolasi bakteri. Kandungan nutrisi yang positif apabila isolat yang di tetesi dengan terdapat dalam suatu media kultur juga H2O2 maka akan menimbulkan akan mempengaruhi pertumbuhan bakteri gelembung. Isolat bakteri yang tidak (Cappucino dan Sherman, 2001). mengasilkan gelembung dapat dinyatakan sebagai katalase negatif. Hal ini berarti H2O2 yang diberikan tidak dipecah oleh bakteri endofit tersebut sehingga tidak menghasilkan oksigen. Bakteri katalase negatif tidak memiliki enzim katalase yang menguraikan H2O2 (Cappucino dan Sherman, 2001).

Dari karakterisasi morfologi bakteri endofit didapatkan hasil bahwa karakteristik koloni bakteri endofit berbentuk bundar, bundar dengan tepian kerang dan bundar dengan tepian timbul, tepian licin, berombak, dan berlekuk dengan elevasi datar dan timbul tetapi dari delapan isolat yang dihasilkan ada enam isolat yang memiliki karakteristik makroskopik sama yaitu bentuk bundar, tepian licin dan elevasi datar. Adanya keanekaragaman dan jumlah isolat bakteri kemungkinan disebabkan oleh media tumbuh yang digunakan sebagai media

Hasil dari karakteristik bakteri endofit dari uji pewarnaan gram didapatkan hasil bahwa seluruh isolat bakteri endofit termasuk jenis bakteri gram negatif dan berbetuk basil (batang) setelah diamati dengan menggunakan mikroskop. Bakteri gram positif ditandai dengan sel berwarna ungu sedangkan untuk bakteri gram negatif ditandai dengan sel berwarna merah (Cappucino dan Sherman, 2001).

Mekasnisme pewarnaan gram didasarkan pada struktur dan komposisi dinding sel bakteri. Bakteri gram negatif mengandung lipid atau substansi seperti lemak dalam presentasi lebih tinggi daripada yang dikandung bakteri gram positif. Dinding sel bakteri gram negatif juga lebih tipis daripada dinding sel bakteri gram positif, dinding sel bakteri gram negatif memiliki ketebalan lapisan peptidoglikannya antara 2-7 nm dan dilapisi oleh membran 
luar dengan ketebalan 7-8 nm. Selama prosedur pewarnaan, perlakuan dengan alkohol terhadap bakteri gram negatif menyebabkan tereaksinya lipid, sehingga memperbesar daya rembes atau permebialitas dinding sel bakteri gram negatif. Jadi kompleks ungu kristal violet yang telah memasuki dinding sel selama selangkah awal dalam proses pewarnaan dapat diekstraksi. Karena itu, bakteri gram negatif kehilangan warna tersebut (Pelczar, 1986).

Berdasarkan hasil uji katalase didapatkan hasil bahwa tiga isolat setelah ditetesi dengan larutan $\mathrm{H}_{2} \mathrm{O}_{2}$ menghasilkan gelembung yang berarti bahwa isolat bakteri tersebut positif menghasilkan enzim katalase. Isolat bakteri yang tidak mengasilkan gelembung dapat dinyatakan sebagai katalase negatif. Hal ini berarti $\mathrm{H}_{2} \mathrm{O}_{2}$ yang diberikan tidak dipecah oleh bakteri endofit tersebut sehingga tidak menghasilkan oksigen. Bakteri katalase negatif tidak memiliki enzim katalase yang menguraikan $\mathrm{H}_{2} \mathrm{O}_{2}$.

Bakteri pada kondisi tertentu akan menghasilkan hidrogen peroksida. Hidrogen peroksida merupakan racun yang dapat merusak sistem metabolisme bakteri. Bakteri akan mengalami kematian apabila tidak dapat memecah hidrogen peroksida menjadi senyawa lain yang tidak berbahaya, pemecahan tersebut dapat dilakukan apabila terdapat enzim katalase (Cappucino dan Sherman, 2001).
Menurut Hadioetomo (1990) enzim katalase akan mengubah hidrogen peroksida menjadi air dan oksigen sehingga tidak berbahaya sehingga bakteri dapat bertahan hidup pada lingkungan yang terdapat hidrogen peroksida. Hal tersebut dapat dilihat pada koloni bakteri yang ditetesi dengan larutan $\mathrm{H}_{2} \mathrm{O}_{2}$ menghasilkan gelembung. Hal ini menunjukan bahwa bakteri endofit tersebut tergolong bakteri aerob, karena memiliki aktivitas katalase. Hal ini sesuai dengan pernyataan Dewi (2014) yang mengatakan bahwa senyawa hydrogen peroksida terbentuk sewaktu metabolisme aerob, sehingga mikroorganisme yang tumbuh dalam lingkungan aerob pasti menguraikan senyawa tersebut.

Mekanisme enzim katalase memecah $\mathrm{H}_{2} \mathrm{O}_{2}$ yaitu saat melakukan respirasi, bakteri menghasilkan berbagai macam komponen salah satunya $\mathrm{H}_{2} \mathrm{O}_{2}$. Bakteri yang memiliki kemampuan memecah $\mathrm{H}_{2} \mathrm{O}_{2}$ dengan enzim katalase maka segera membentuk suatu sistem pertahanan dari toksik $\mathrm{H}_{2} \mathrm{O}_{2}$ yang dihasilkannya sendiri (Murali, 2017). Bakteri katalase positif akan memecah $\mathrm{H}_{2} \mathrm{O}_{2}$ menjadi $\mathrm{H}_{2} \mathrm{O}$ dan $\mathrm{O}_{2}$ dimana parameter yang menunjukkan adanya aktivitas katalase tersebut adalah adanya gelembunggelembung oksigen seperti pada percobaan yang telah dilakukan. Gambar dari isolat bakteri endofit yang berptensi penghasil enzim katalase dapat dilihat pada gambar 1 sampai 3 berikut. 


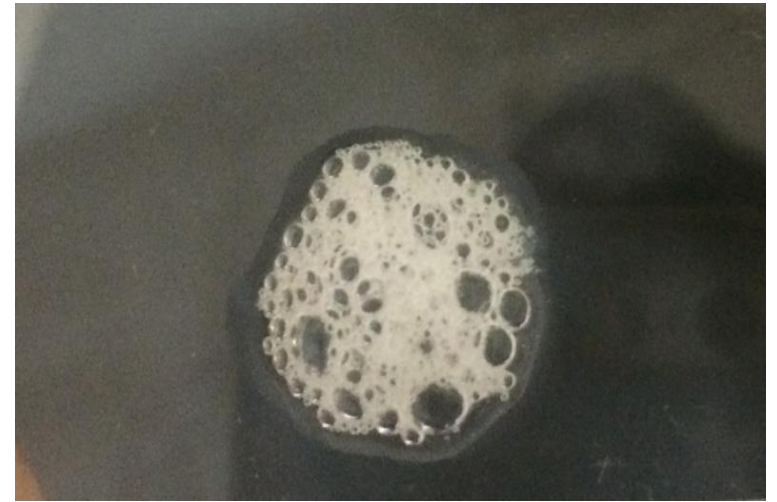

Gambar 1. Isolat bakteri endofit penghasil enzim katalase

Enzim Katalase banyak digunakan dalam industri makanan untuk menghilangkan hidrogen eroksida dari susu dalam produksi keju. Penggunaan enzim katalase lainnya adalah digunakan dalam pembungkus makanan untuk menghindari terjadinya proses oksidasi pada makanan yang dibungkus. Enzim katalase juga digunakan dalam proses indusri tekstil, dimana hidrogen peroksida dihilangkan dari kain untuk memastikan bahwa kain tersebut bebas dari kandungan peroksida. Potensi dan manfaat enzim katalase yang begitu besar, dimungkinkan untuk mendapatkan enzim tersebut dengan memanfaatkan bakteribakteri endofit dari berbagai sumber.

\section{SIMPULAN}

Pada daun Buasbuas diperoleh isolat bakteri endofit. Dari hasil karakterisasi isolat bakteri endofit pada karakterisasi mikroskopis (pewarnaan gram) didapatkan hasil bahwa keseluruhan isolat bakteri endofit memiliki bentuk batang (basil) dan termasuk dalam gram negatif dan tiga isolat positif pada uji katalase.

\section{DAFTAR PUSTAKA}

Cappucino, J. G., Sherman. N. (2001). Microbiology : A Laboratory Manual. Edisi Kedua. New York : Benjamin Cummings Publishing Company

Dewi, Mita Kusuma. (2014). Aktivitas Antibakteri Ekstrak Daun Majapahit (Cresentia cujete) terhadap Pertumbuhan Bakteri Ralstonia solanacearum Penyebab Penyakit Layu. Jurnal Lentera Bio. 3(1) : 51-57

de Sousa, C.P., Serrano, N.F.G. and Lacava, P.T. (2017). Endophytic Microorganisms of the Tropical Savannah: A Promising Source of Bioactive Molecules. In Diversity and Benefits of Microorganisms from the Tropics (pp. 57-7o). Springer, Cham.

Gholib, Djaenudin. (2009). Daya Hambat Ekstrak Kencur (Kaempfera galanga L.) Terhadap Trychophyton mentagrophyes dan Cryptococcus neoformans Jamur Penyebab Penyakit Kurap Pada Kulit Dan Penyakit Paru. Bul. Littro. Vol. 20 No. 1, Hal : 59-67

Hadiutomo. (1990). Mikrobiologi Dasar Jilid I. Jakarta: Erlagga.

Kusumawati, Dwi Endah. (2014). Isolasi Dan Karakterisasi Senyawa Antibakteri Dari Bakteri Endofit Tanaman Miana (Coleus scutellariodes [L.] Benth.). Tesis. Sekolah Pascasarjana Institut Pertanian Bogor

Lay, B. (1994). Analisis Mikroba di Laboratorium. Jakarta : Rajawali

Miller CM, Miller RV, Garton-Kenny D, Redgrave B, Sears J, Condron MM, Teplow DB, Strobel GA. (1998). Ecomycins, Unique Antimycotics From Pseudomonas viridiflava. Appl Microbiol 84: 937-944

Murali, A. and Patel, S., (2017). The Effect of Different Heavy Metal Acetate Solutions on the Inhibition of Catalase Enzyme. Journal of the South Carolina Academy of Science, 15(2), p.13.

Pelczar dan Chan. (1986). Dasar-dasar Mikrobiologi Jilid 2. Jakarta : Universitas Indonesia 
BioLink, Vol.5 (1) (2018): hal. 72-80

Pulungan, A.S.S. (2015). Pemanfaatan Mikroorganisme dalam Bioremediasi Buasbuas Leaves (Premna pubescens) As Immunostimulant On Rats (Rattus Senyawa Pencemar. Jurnal Biosains, 1(1), pp.75-84. novegicus). American Journal of BioScience. 2(6):244-250

Radji, M. (2005). Peranan Bioteknologi dan Mikroba Endofit Dalam Pengembangan Obat Herbal. Majalah Ilmu Kefarmasian. Vol. II No. 3, 113-126

Ryan RP, Germaine K, Franks A, Ryan DJ, Dowling DN. (2008). Minireview: Bacterial Endophytes: Recent Development And Application. FEMS Microbiol Lett 278: 1-9

Restuati, M.,Ilyas, S., Hutahaean,S.,Sipahutar, H. (2014). Study of The Extract Activities of 